\title{
The meaning of the diakon word group in John 12:26 applied to the ministry in congregations
}

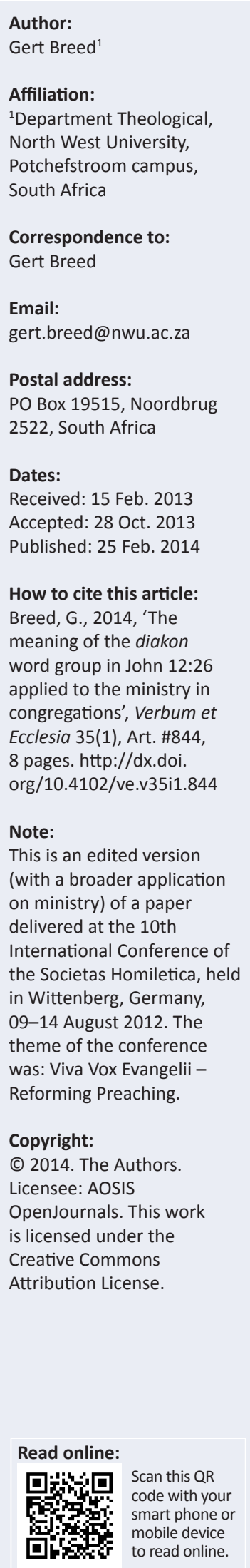

This article investigates the meaning of the diakon word group in the Bible with the focus on the use of this word group in the Gospel of John. John 12:26 is considered in depth. The results of this investigation reveal important differences from other recent research on this word group. The results of the research are then applied to the ministry in congregations.

\section{Introduction}

Research on the diakon word group was triggered anew by the study of Collins (1990) and later gained momentum with studies by Hentschel (2007) and others (see Arndt, Danker \& Bauer 2000; Breed 2012a, 2012b; Breed \& Breed 2010; Collins 2009; Donfried 1990; Gooder 2006; Latvus 2010). These researchers agree that the diakon word group does not have the exclusive or general meaning of humble service motivated by love for one's fellow man but rather appears in the semantic context of a representative, messenger or envoy. However, much disagreement still exists on several aspects related to the use of this word group (Clarke 2000:233-245; Gooder 2006:33-56; Hartley 2004:367-380; Latvus 2008:144-149). ${ }^{1}$

Although most parts of Scripture where this word group appears have been studied, not all of them have been adequately investigated. Moreover, often the Scriptural context in which the word group appears has not been taken into account adequately. Little attention has been paid to the Gospel of John in this regard (Collins 1990:12, 48, 245, 248; Hentschel 2007:10, 16, 214, 236, $248,257,286,340,341)$.

This article aims to provide an exegesis of John 12:26 and to investigate the meaning of the diakon word group. After having considered the exegetical results, the existing research on this word group will be critically evaluated. In investigating the meaning of the diakon word group, the importance of the Scriptural context, the book and the chapter in which the words occur will be taken into account at all times.

The results of the research will then be applied to the ministry in congregations.

\section{John 12:26}

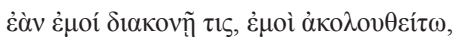

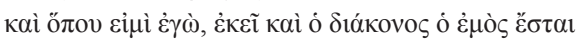

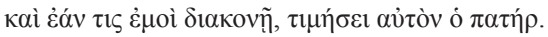 \\ If any man serve Me, let him follow Me; \\ and where I am, there shall also My servant be: \\ if any man serve Me, him will My Father honour. (King James Version [KJV])
}

\section{Who can be Jesus' diakonos?}

In an inquiry into the semantic range in which the diakon word group is used in this verse, it is important to establish to whom the indefinite pronoun tis refers. According to Louw and Nida (1988:814), it indicates someone or something undefined. Verse 26a could in other words be translated as follows: 'If anyone serves Me.'

Considering the context in which this verse appears, to whom is Jesus speaking? Throughout the chapter, Jesus is presented as surrounded by crowds of people who, after the resurrection of Lazarus, came to see Lazarus and Jesus. Many were there for the Passover. The high priests

\footnotetext{
1.For various definitions and the discussion on the meaning of the diakon word group in the New Testament, see my previous articles (Breed \& Breed 2010; Breed 2012a:1-8, 2012b:4, 5). Louw and Nida (1988:59) lists 14 different meanings of the word group but stil have the opinion that it basically denotes humble service. Whilst Arndt et al. (2000) changed the description of the meaning of the word group from that in the previous edition of their dictionary, in this most recent edition, they used the results of Collins' work on this
} word group as stated above in the introduction. 
adjudicated the event by the telling words: 'Behold, the world is gone after Him' (Jn 12:19). The author presents these words by the high priests as prophetic because just after quoting their exclamation he mentions the arrival of the Greeks who asked to see Jesus (Jn 12:20; Salier 2004:22). Jesus referred to this incident later when he said that his crucifixion would result in him drawing all (pantas) to him (Jn 12:32). The drawing to him of all people began with the arrival of the Greeks (Painter 1991:323). The new pattern according to which people would come to Jesus took shape at that point. That was the hour that had come (Jn 12:23). In future times, when Jesus would be on earth no longer (when he would have been elevated), people from all over the world would be drawn to him by his followers (like Philip and Andrew). John 12:26 should thus be understood in light of the worldwide following of Jesus (Obielosi 2008:250). The word tis, therefore, refers literally to anybody from any part of humanity who wants to serve Jesus.

From verse 29, it is clear that Jesus was again surrounded by a crowd of people when he spoke the words in verse 26 , reacting directly to the request of the Greeks to see him. It is not clear whether the Greeks were present or not when he uttered the words. In either case, Jesus' words were an answer to the request of the Greeks - perhaps communicated to them by the disciples. The arrival of the Greeks also made it clear to Jesus that the hour of his final suffering and death had arrived (vv. 23, 24; Salier 2004:123). Therefore, at that moment, he proclaimed to all what it entailed to serve him. Jesus spoke to the Greeks, to his disciples, to the entire crowd and even to those leaders that believed in him but did not want to confess it out of fear (Jn 12:42). The directive in John $12: 26$ is therefore a general prescription that holds true for every believer. Due to the frequency of the diakon word group in this verse, the directive may be viewed as a definition of a diakonos of Jesus Christ (Lee 2010:118).

The opinion of Collins (2006, 1990:194) that diakonia in the New Testament primarily describes the service of people in the special services (offices) is questionable because of John's definition of diakonia, which is founded on the words of Jesus. It is clear that the author of the Gospel of John is of the conviction that every person who follows Jesus could be a diakonos, that is, a servant of Jesus.

\section{Serve (diakoneo) and follow (akoloutheo)}

It is clear from verse 26 that a person cannot serve Jesus if such a person does not follow him. It is therefore important to establish what follow means in the context of John 12:26. John 12 forms the conclusion of the first part of the Gospel of John (Thomas 2004:80; Van der Watt 2008:91). The first part (chapters 1-12) is often referred to as the book in which Jesus' miracles are described. The second part (chapters 12-20) is referred to as the book that narrates the suffering (and glorification) of Christ (Hamilton Jnr. 2010:407, 415; Thomas 2004:61, 62).
Coetzee (1976) provides the following structure for the book:

Introduction: 1:1-51

Body: 2:1-20:31

Part 1: Signs followed by claims $-2: 1-7: 52$

Part 2: Claims followed by signs $-8: 12-11: 54$

Part 3: Signs followed by claims - 11:55-19:16

Part 4: Final signs with apophthegms interwoven - 19:17-20:27

Part 5: Climax and conclusion - 20:28-31

Epilogue: 21:1-25

Appendix: 7:53-8:11. (p. 15, [author's own translation])

John 12, therefore, forms part of the third section of the body where signs are followed by claims. Coetzee (1976:15) calls John 12:1-50 the first episode in which Jesus, the true King who came to die for his people, is described.

John 12 starts with the announcement that Jesus arrived in Bethany 6 days before Passover. In the sentences following the announcement, the evangelist links Jesus' arrival to the resurrection of Lazarus, Jesus' anointing by Mary as well as Judas' betrayal (vv. 1-4). All three these events pointed to Jesus' death. Lazarus' resurrection also prepares the reader for Jesus' resurrection. Jesus' explanation of Mary's deed made it clear that he would die and be buried and that he would not be with them forever. The resurrection of Lazarus caused the crowds to flock in. This finally convinced the leaders of the Jews that Jesus had to be killed. The entire chapter bears the stamp of Jesus' approaching suffering and death (Thomas 2004:81). However, Jesus was also glorified as King and Messiah by Mary's anointing, the crowds, the Greeks and the Father. The contrast between the King who had to suffer and die and the King who would conquer through death runs through the entire chapter.

The image that Jesus used (v. 24) to explain the necessity and purpose of his death combined all these themes. Jesus was like a grain of wheat that had been sown, and the grain had to die to fulfil its purpose, namely to carry much fruit (v. 24). The 'much fruit' comprised everybody whom Jesus would draw towards him (v. 32). Jesus said that his soul was distraught in anticipation of his suffering. Inside himself, the question arose whether he could ask the Father to save him from the hour of death (Jn 12:27, 28). However, he concluded that he could not do that because the purpose of his coming to the earth would be fulfilled by the events during the hour of his suffering and death. Therefore, his decision was that he would rather glorify his Father by completing the charge (vv. 27, 28; Köstenberger \& Swain 2008:69). In conclusion, to

2. Bruner (2012) gives the following broad structure: John 1-12-Jesus' public ministry John 13-17- Jesus' discipleship sermons and prayer; John 18-21 - Jesus' passion and resurrection. John 12 forms a turning point in this structure. Neyrey (2007:225-226) also divides the gospel in two, naming John 1-12 'The book of signs' and John 13:1-3 'The second prologue'. He views 13:1-3 as the introduction to John 13-21, 'The book of glory'. He says that John 12 is the fulfillment of the prediction made in the first prologue that Jesus will be rejected by his own and by the world but that there wil be those who will receive him. Starting from John 13, Jesus works with those who received him, his diakonoi. Moloney (2005:32) also names John 1-12 'The book of signs'. He divides the signs into three parts, the inaugural signs $(2: 1-11,2: 14-17$, $2: 23 ; 3: 2 ; 4: 41-45)$, signs amidst mounting controversy $(5: 1-15 ; 6: 1-15,9)$ and the climactic sign namely the raising of Lazarus (Jn 11). According to him, John $12 \cdot 20$ 50 describes 'the dawning age of the Gentiles and the signs of the Mes John 12:2050 describes 'the dawning age of the Gentiles and the signs of the Messiah rejected by the old covenant community'. According to his structure, chapters 13-20 are 'the book of glory' and describes 'Jesus' passion and preparation of the new covenant community'. It is clear from these structures that John 12 can be regarded as a turning
point in the gospel. 
follow Christ means to come to the same decision, completing the charge, after consideration and to fulfil the task given by the Father even if it means your death. Mullins (2003:289) says that the point of contrast is found in the words 'alone' and 'much fruit'. Commanding followers of Jesus to die so that they may live is thus also a command to bring people to Jesus.

The structure of verses 23-28 makes it clear that, whoever served Jesus, were to participate in the events of his hour of suffering and death (Neyrey 2007):

- verse 20-22: the Greeks' request - they wanted to speak to Jesus

- verse 23: Jesus' answer that the hour of his glorification had come

- verse 24: Jesus' explanation of the 'hour' by the image of the grain of wheat that had to die

- verse 25: Jesus' application to his followers of the principle of life through death (Kim 1999:65)

- verse 26: Jesus' explanation of what it means to serve Him

- verse 27: Jesus expressing his anxiety about his hour of suffering and death, his inner conflict and his conclusion that He did not want to sidestep the hour, but wanted to glorify the Father. (p. 215)

Verse 27 (Jesus' exposition of the hour) continues where verse 24 (the announcement that the hour had come and the meaning of the hour) has left off, and verses 25 and 26 are insertions that describe the influences of the hour on those who want to serve Jesus (Ridderbos 1992:68). The structure used here makes it clear that Jesus' followers were made part of the hour that had come for Jesus with the arrival of the Greeks. ${ }^{3}$ The request of the Greeks not only ushered in the particular hour in Jesus' life but also a particular hour in the lives of those who served him. Jesus' assignment was limited to the Jews (Mt 15:24); the disciples would carry the Gospel to the nations. The hour in which Jesus' task was transferred to his followers concurred with his glorification, which came to life in his death, resurrection and ascension. Serving Jesus means to follow him; following him means to participate in his task. This directive requires that one should be willing to lose one's life, in this manner bearing much fruit in order to glorify God (v. 25; MacArthur 2005:11; Thomas 2004:80; Van der Watt 2008:89; Von Wahlde 2010:555).

'Within the confines of the antithetical parallelism in 12:25-26, service functions as explanation of what it means to hate one's life' (Van der Watt 2008:91). Serving Jesus does not mean that one should attempt to repeat his unique reconciliatory work but rather that one should, like him, be willing to give one's life in the service of God and his calling so that there will be much fruit to the glory of God (Ridderbos 1992:70-71).

The diakon word group is not used in John 12 to describe the social service of love but service to other people as a directive from God. The aim is to realise Jesus' victory over

3.Compare Neyrey (2007:214), who indicates a chiastic structure in 12:23-26 where Jesus' hour of glorification $(12: 23)$ and the honour that those who serve him receive from the Father (12:26c) form the A-A leg. The B-B leg is formed by the image of the grain of wheat (12:24) and the directive that believers should be willing to lose their lives (12:25-26b). die wicked in one's life so that one will also be diakonos and a follower of Jesus. Being diakonos means to be a disciple, and a disciple should serve as Jesus served. This refutes the radical distinction that Hannaford (2005:83-88) draws between diakonia and discipleship. Hannaford argues that discipleship comprises the entire life of the believer whilst diakonia only refers to service work that carries a sacramental character and that is completed on behalf of the church (Hannaford 2005:88).

\section{Serving, following and loving}

To love Jesus above everything, even your own life, means that you will hate anything that may come between you and serving Jesus (12:25).

Jesus revealed the love of God in his death through which he conquered sin and Satan (1 Cor 15:54-56; Heb 2:14). This is the Gospel as John describes it. This is the Word the Father proclaims to all people through Jesus, saying: 'For God so loved the world that he gave His only begotten Son, that whosoever believe in him should not perish, but have everlasting life' (Jn 3:16). In John 12 and elsewhere, the evangelist tells that Jesus repeatedly referred to the Father who had sent him. In John 17, the evangelist reports Jesus' description of the faith of the disciples, namely that they were the ones who believed that the Father had sent him. The aim of Jesus' victory was to attract all to him. In John's description of the Gospel, the emphasis is on relationships. Jesus revealed the relationship between him and his Father - they are one. Jesus glorified the Father by only doing and saying those things that the Father had sent him to say and do and by completing his assignment in that manner. He revealed their relationship and fulfilled his calling on this earth (see 17:4). His purpose was to bring his servants to understand the relationship between his Father and him and to believe that he had been sent so that they would be able to take part in the relationship. The possibility for the servants of Jesus to understand, believe and become part of this relationship flowed from the Father's love for the world.

In John 13, it becomes clear that the execution of Jesus' assignment was founded on his love for his own people; it was a love to the extreme (death) (13:1). It is also clear from the following that John 13 is closely linked to John 12. Both chapters reflect the fact that Jesus' hour had come with the approaching Passover as background. Jesus washed the feet of his disciples, an act which the evangelist links closely to Mary's anointing of Jesus' feet. Jesus became distraught about the hour of his suffering, something that was confirmed by the betrayal by Judas (12:27 and 13:21). Judas' departure confirmed the dawning near of Jesus' glorification by the Father and, through that, the glorification of the Father (13:3, $32)$. The arrival of the Greeks was a similar confirmation (12:20-23). Jesus involved the disciples in his directive and called them messengers (12:25-26 and 13:14-17). Those who follow Jesus in being messengers would experience joy (12:26 and 13:17). Chapter 13 concludes with the narrative 
of Peter, who followed Jesus, but who had to hear that he would betray Jesus. This chapter may rightfully be viewed as a more detailed elaboration of Jesus' hour of suffering and glorification and therefore of what it means to serve and follow Jesus (Clarke 2000:240).

Van der Watt (2008) indicates that, in the rest of the Gospel according to John, the meaning of diakonia is described in more detail:

All the references to following in chapters 13-21 are to Peter (except 21:20 that refers to the other disciple, although Peter is mentioned as seeing this disciple). As will be argued, this is significant. Peter becomes the narratological example of what it means to come to the point of laying down one's life and being a servant. In the end he will indeed follow Jesus where He goes. (p. 91)

He (Van der Watt 2008:92) continues that by arguing that John 12:23-26 closely correlates with John 13:31-14:3 with regard to word use and the themes addressed. By comparing 13:31-38 and 21:15-22, he indicates six thematic agreements between these two parts and concludes as follows (Van der Watt 2008):

The focus does not fall on Peter dying, but on him serving the Lord lovingly by caring for the sheep of the Lord. In chapter 21, his willingness to lay down his life is interpreted in terms of His loyal service. This is what is required from a servant according to 12:25. In that sense dying (hating his life/serving in terms of 12:26), reinterpreted by the implied reader in terms of 12:25-26, implies caring, tending and feeding the Lord's sheep. (p. 93)

Serving Jesus means loving him as well as his followers so much that one would be willing to lay down one's life in executing the directive from the Father to lead people to Jesus and to care for his flock. Diakonia is inseparable from the humble and sacrificial service of love of Jesus as described in John 13 and from the directives to Peter in John 21:15-22. In Peter's case, it means care for the flock of the Lord (Jn 21:15-22), but Jesus also said unambiguously that it might mean something else to another diakonos, namely John (Jn 21:20-22).

The study of the diakon word group in John 12 confirms the finding that this word group does not express a moral, ethical love service (Collins 1995:159-178), but a diakonos who, according to John, is someone dispatched by God with a specific mandate. However, diakonia is closely linked to love for God and God's children. The author of the Gospel does not hold the conviction that diakonia has nothing to do with love for your fellow human being as Collins (1995:159-178) suggests. Researchers that separate the diakonos as 'messenger' from the 'someone providing service of love' impoverish the meaning of this word group (Collins 2002:87). Elliot (2000:755, 756) also shows the error of Collins (1990:232) when the latter minimises the expression of service in mutual love by the diakon word group. The necessity of studying the diakon word group in Scriptural context has been proven clearly by the preceding research. It disproves Collins' claim that John 13 has nothing to do with Jesus' diakonia. However, he is correct when saying that service work does not describe the work of the individual as distinct from the congregation but that it is service that flows from the unity between believers mutually and between believers and their Lord. This becomes quite clear from the link established between John 12 and 13 (Jn 13:12-17; cf. Hannaford 2005:83).

It seems from the use of the diakon word group in John 12 that this word group is filled with a particular Christian content. This assumption is made because of the suggestion of Elliot (2000:755-760), mentioned above, on the use of these words in 1 Peter. However, this will have to be confirmed in follow-up articles on studies concerning different parts from Scripture.

\section{Jesus' diakonos will be where he is}

Place and movement play a very important role in John 12 (Obielosi 2008:244). In it, constructs referring to place and movement are used with two meanings. Firstly, they may indicate the physical place where you finds yourself or the physical place where you are going. Secondly, they may refer to the place where the people are with whom you cast your lot. The meaning of the words of 12:25 and 26 should also be understood in this light. The fact that the diakonos of Jesus will be where Jesus is can be explained as follows. The detailed description of Jesus' movements, the places where he went and what he did there reflect where he was in his heart. In his heart and his conviction, he was at the place where he had to go to meet the hour of suffering intentionally because he wanted to glorify his Father and because he wanted to bear much fruit, like a dying grain of wheat. He did that by attracting many to him. He was driven to go where he went and to say what he said out of love for his Father and for those who wanted to serve his Father - so that Father and Son, and those who served them, would be glorified. By acting in that way, he was the true diakonos who served his Father as well as those who followed him.

Those who served him had to follow his example by going wherever they were needed (see 21:18-19) and saying whatever was needed so that Father and Son, as well as those who followed Jesus in their diakonia, could be glorified. According to Anderson (1999:42), this fact is expressed in 12:25-26:

He that hath loveth His life shall lose it; and he that hateth His life in this world shall keep it unto life eternal. If any man serves me, let him follow me; and where I am, there shall also my servant be: if any man serve me, him will my Father honour.

Such servants, no matter in what times they live, will be where Jesus is, not only in his suffering but also in his glory. He will be where Jesus is in his attitude, namely to be willing to give his life so that everyone can be drawn to Jesus. He will one day view Jesus' glory when he is with Jesus forever (Jn 17; Van der Watt 2008:94). He will also, like Jesus, triumph as king over evil (12:31).

In John 12, four diakonoi with this attitude are sketched. At first glance, verses 1-3 look like unnecessary information. The reader's attention is caught by the use of the verb diakoneo to describe Martha's service to Jesus and Lazarus. She looked 
after their needs and did not think of herself but of them. Subsequently, Mary is described using expensive balm with which she served Jesus. In verses 7 and 8 , it is said that the crowd who had seen that Jesus resurrected Lazarus from death acted as witnesses so that people glorified Jesus as King when he rode into Jerusalem on the donkey (Anderson 1999:38). Lazarus is clearly highlighted as an agent through whom people came to faith because they could see in him that Jesus had the power to command life from death (12:9-11). In the same chapter, John relates how Philip and Andrew became the instruments through which the message of the Greeks, who wanted to see Jesus, reached him. However, several people that did not believe or identify themselves with Jesus are also sketched in this chapter. In 12:4, Judas, in contrast to Mary and Martha, is sketched in his greed and falsity. The negative reaction of the Pharisees is shown in 12:10, 19, 42 and 43. In 12:37-40, the hard-heartedness of some in the crowd is described. Through them, the prophecy of Isaiah, that some would turn a deaf ear to the Word, was fulfilled.

Anderson (1999:38) indicates that the Christology in the Gospel according to John is inseparably linked to Jesus as Messenger of the Father. He was, as Moses had been (Dt 18:15-19), God's agent, who spoke and acted on behalf of the Father and with the Father's authority. In John, the emphasis is not on Jesus' conquering death, in which he carried the wrath of God, but on faith. People came under God's judgement due to unbelief; they were saved because they believed that the Father sent the Son to save them (Koester 2005:147). The fact that Jesus was sent by God entailed that Jesus himself did not judge the unbelievers. He himself said that his words would judge them because they were the words of the Father who had sent him (12:47-50). Those who accepted his testimony would become one with him like he was one with the Father (John 17), and in this regard, they were where Jesus was (12:26). Even as in the time of Jesus, serving Jesus means that he will be followed also in the task that the Father laid upon him, namely to bring the Father's words to people.

The diakonos of Jesus is therefore also an agent who communicates the words of Christ - which are the Words of the Father - to others. The aim of the communication is that the others should accept the words in faith and believe them and that they would be drawn to Christ by the words. Whoever believes and follows Jesus serves him, and whoever serves Jesus will be with him. It is clear from John 15 and 17 that being with Jesus entails that believers become part of the community between the Father and the Son and that believers are one with each other. When this unity becomes visible, it makes the testimony of the believers effective so that others will also come to the faith (see 17:20-23; Kysar 2001:372).

\section{Serve and honour}

Jesus described the hour that had come as the hour of his glorification. He also said that whoever served him would be honoured by the Father. The hour that came for Jesus was the hour of his final suffering, crucifixion and death. The question is how the events that led to his death on the cross could also be his glorification. John 12:31-33 provides a possible answer. When Jesus was crucified (exalted), the judgement came over the world. The leaders of the world were driven out (John 12:31), and Jesus will draw close to him those whom his Father had given him. In that way, he completed the task for which he had been sent to the world. Whilst glorifying the Father, the Father glorified him. John presents Jesus' death, resurrection, ascension and enthronement in such a way in his Gospel that it becomes one big moment of glory (Romanowsky 2005:101). For Jesus, death and suffering go hand in hand with glorification, and the same holds true for those who serve him. His servants should be willing to die in executing their task, safe in the knowledge that the Father will honour them (Dennis 2006:335).

Koester (2005:153) formulates the relationship between cross and glorification as follows: 'If glory defines what the crucifixion is, the crucifixion defines what glory is. The crucifixion manifests the scope of divine power by disclosing the depth of divine love.'

In John 13:1-5, the hour of Jesus' final service is linked to the fact that he came from the Father and will return to the Father. However, it is also linked to the fact that the Father gave everything into his hands. In the middle of this description of his service, the work of Satan and Judas is mentioned (Moloney 1998:372).

Jesus' diakonia was enacted with the certainty of his being sent by the Father and of his glorification by the Father on his return to the Father, but it is also enacted with the certainty that he would conquer evil because the Father had enabled him to do so (had given all things in his hands). These verses clearly expand on John $12 .{ }^{4}$ In John 12:26, the statement that the Father would honour Jesus' diakonos and the diakonos' task is linked to the purpose of Jesus' coming to earth (12:26, $27)$ as well as to the expulsion of evil (12:31). When John 12:26 is read with 13:1-5, it is clear that the diakonia of a follower of Jesus is also enacted with the certainty of the honour that the Father gives (Hentschel 2007:10). This honour includes the certainty of the victory over evil and the certainty that the follower will be with Jesus (also see Jn 14:1-3; 17:41) and will be one with the Father and the Son (also see Jn 17:11, 21-23).

The people who did not want to confess Jesus openly (Jn 12:42) are described as people who had higher regard for the honour they received from people than for the honour that God gave (12:43). In other words, they wanted to serve Jesus without following him in his suffering and his glorification. Serving and following Jesus include the willingness to openly confess him (homolegeo $=$ to say the same, to agree).

\section{Preliminary conclusions}

It is now necessary to draw some conclusions out of the first exegetical part of the research because the next part shall build on these results:

4.Ridderbos (1992:91) says that the things that are predicted in chapters 11 and 12 are starting to happen now. 
- In John 12:26, the meaning of the diakon word group has to be found in the link with following Jesus, unity with Jesus (being where he is) and glorification by the Father.

- Following Jesus entails that the diakonos serves Jesus by taking as his or her own Jesus' task of drawing people near to him.

- Being where Jesus is entails that the diakonos becomes part of Jesus' suffering, death and unity with the Father.

- To be honoured by the Father means to take part in the mutual glorification of Father, Son and diakonoi. The certainty that this glorification offers through the Father enables the diakonos to serve and follow Jesus.

- A diakonos of Jesus distinguishes the hour of God's providence in her or his life and intentionally chooses to serve God in what that hour demands of her or him.

- Service to others is founded on Jesus' victory. Because the diakonoi are convinced of Jesus' victory, they put the victory of their Lord into effect by providing service out of boundless love to others. In this way, they are messengers proclaiming the message of God's love for the world.

- The meaning of the diakon word group is found in the mutual unity of the believers (ecclesiologically) and their unity with their Lord.

- 'The crucifixion manifests the scope of divine power by disclosing the depth of divine love' (Koester 2005:153). Thus, the diakonoi discloses God's love by sacrificing themselves in service so that the divine power can be manifest through their service.

- Jesus conquered the evil with his diakonia to the Father and established his kingship by fulfilling all that the Father commanded him to do.

The next part of this article will look at the significance of these conclusions for the practical ministry in a congregation.

\section{Significance for the practical ministry in the church}

When a congregation accepts the Bible as Word of God, John 12 should play a role in the way they perform their ministry. The following guidelines can be deduced from the foregoing exegetical research (cf. also Breed 2012b).

\section{You cannot be a follower of Jesus and not serve}

One of the basic assumptions of every congregation should be that a diakonos follows Jesus in his diakonia. A follower of Jesus is either involved in ministry, or he or she is not a true servant of Jesus. That means that no one in the church should be allowed to avoid service in any way. The members of a congregation must be purposefully equipped and inspired to perform their ministry with the same attitude as Jesus. Ministry (diakonia) means following Jesus in his obedience to and relationship with the Father with the resolution to honour God and in expectation of God's honour, which they will experience.

\section{All ministries are God's ministry}

It is important for both the leaders of the congregation and all the members to understand the ministry they have. Further, when performing the ministry, they should experience it as God's ministry to and through them. The certainty of being merely a servant called to work with the Lord in his ministry is the source of the congregation's endurance and readiness to sacrifice as much as the task ahead may demand of them.

The congregation are performing the Lord's ministry, not their own. This view on ministry must be an integral part of every equipping opportunity, the way the congregation talk about ministry, how they decide what to do and what not to do and the way in which they pray, preach and teach. When this is the attitude towards ministry, the congregation would be able in less fruitful times to wait patiently for God's time. Whereas the Holy Spirit was sent by Jesus to teach, guide and comfort his followers, all ministry will be performed prayerfully, seeking to be filled with the Holy Spirit (Eph 5:18).

\section{Ministry results in the experience of unity}

The congregation must be led to experience their unity by equipping them to serve each other and guiding them to receive the ministry willingly from each other. The more they are willing to open up their deepest hurt, anger, sins and doubt, the better they can minister to each other, and the deeper the unity grows.

Together they must be led in the worship service and everywhere else to experience their unity with the Lord and each other. They must experience the depth of the existing unity between the diakonos and their Lord and the existing unity between the diakonoi of the Lord. The promise of Jesus that the Father will honour his diakonos must be an integral part of the proclamation of the Word and every equipping opportunity. The mutual glorification of the Father and the Son and the diakonoi is a natural fruit of the ministry performed under guidance of the Holy Spirit. The certainty of the glorification by the Lord, now and finally when Jesus returns, must be cultivated in the minds and hearts of the diakonoi. Honouring each other for the ministry performed in the service of the Lord is part of this cultivation and growth process and an important part of the experience of unity. This way of ministry to and by the congregation is in stark contrast to an attitude of serving just to fulfil your duty or just out of concern about the on-going existence of the congregation or even seeking the honour that men will give.

\section{All ministries are focused on drawing people to Jesus}

Jesus establishes his kingdom with the diakonia of his followers who are ready to sacrifice their lives in the service of their Lord. Diakonia is used by the Holy Spirit to draw people to Jesus. Serving each other and loving each other in the congregation will take place in the expectation that the Holy Spirit will use such ministry to equip and cultivate the congregation to maturity so that they can serve the world despite the dangers that lurk in giving yourself to unbelieving people. The congregation must be equipped to 
the point that they live their lives because of the conviction that God's power will be manifested when they are ready to be crucified, disclosing the love of Jesus. The Holy Spirit will use the diakonia of the congregation to conquer (some of) the evil in the congregation and wherever they live. The congregation must be ready to serve and give themselves in the expectation that God will use their ministry to draw people to Jesus.

\section{Ministry is a celebration of the victory of Jesus}

According to John 12:31, the certainty of the victory that Jesus anticipated is the starting-point of his followers' diakonia. The gifts that he bestows on his church are gifts of accomplished victory. Using these gifts in the ministry, the church is celebrating his victory and the love that made the victory possible. The members must be trained to live up to their identity as victors with Jesus. They have to know for certain that they do not have to accomplish the victory - Jesus did that. They only have to use the gifts to serve so that it may become clear that the victory had been accomplished. The diakonia of the followers of Jesus is the weapon they are using to drive back the enemy and broaden the reign of their King to whom was given all the power in heaven and on earth. The liturgy of the worship service must always be a celebration of the victory of Jesus to prepare the congregation for the liturgy of life where they will also celebrate his and their own victory by serving each other and the world. Diakonia means following Jesus in his victory over self-centeredness and unbelief, rather believing that the Father will provide in all circumstances. Diakonia flows from the conviction that I am a diakonos, sent by Jesus to serve him in love. Through God's providence, there may come a time (an hour) that places the followers of Jesus before the choice to try to save themselves or to be obedient and serve God whatever the consequences may be. By choosing to be obedient, the victory of Jesus is celebrated. Wherever God's people are equipped for the ministry, they must be brought to confirm this choice in their hearts and minds. Under the guidance of the Holy Spirit, the diakonoi of Jesus will discern the specific hour in their lives and what God asks of them in that hour.

\section{Conclusion}

John 12:26 was considered in depth to establish the meaning of the diakon word group as it is used by John. Some of the results were already summed up in the preliminary conclusion and will not be repeated here. The results of this investigation also revealed important differences with other recent research on this word group. The main differences are:

- John used the diakon word group to describe the ministry of every believer and not just that of the special services (Collins 1990:194, 2006).

- John used the diakon word group to describe service that is in the first place done by a human being as an agent of God but also out of love for others. Researchers that separate the diakonos as 'messenger' from the 'someone providing service of love' impoverish the meaning of this word group (Collins 2002:87; Hentschel 2007:1).
- The research showed that it is possibile that the diakon word group in John 12 is filled with a particular Christian content. However, this will have to be confirmed in followup articles on studies concerning different parts from Scripture. This is contra the opinion of Collins (1990).

- It became clear through the research that there is a definite link between John 12 and 13 and that the meaning of the diakon word group in John 12:26 must be read in light of this unity. This has to be explored further. This finding defied the opinion that Jesus' action of washing his disciple's feet and his command to love each other in John 13 do not have any importance for establishing the meaning of the diakon word group in John 12:26 (Hannaford 2005:83).

- It was established that diakonia and discipleship cannot be separated as some (Hannaford 2005:88) researchers do. According to John, diakonia can be done at any time and in any place in the life of a follower of Jesus as long as it is the words and the deeds according to the will of the Father. Diakonia thus does not only comprise service work that carries a sacramental character and that is completed on behalf of the church (Hannaford 2005:88).

- The importance to take into consideration the context of the book, chapter and verse where the diakon word group is used was established. This is the critique against Collins (1990), raised also by other researchers (Clarke 2000:240; Gooder 2006:50, 51), namely that he did not take the context into consideration sufficiently.

The practical implications of the research were applied to the ministry in congregations, and it became clear that further investigation on the meaning of the diakon word group, as used in the rest of the New Testament, can yield important guidelines for the practical ministry in congregations.

\section{Acknowledgements Competing interests}

The author declares that he has no financial or personal relationship(s) that may have inappropriately influenced him in writing this article.

\section{References}

Anderson, P.N., 1999, 'The having-sent-me Father: Aspects of agency, encounter, and irony in the Johanine Father-Son relationship', Semeia 85, 42.

Arndt, W., Danker, F.W. \& Bauer, W., 2000, A Greek-English lexicon of the New Testament and other early Christian literature: Based on Walter Baur's Griechisches- Deutsches Wörterbuch zu den Schriften des Neuen Testaments und der übrigen urchristlichen Literatur, 3rd rev. edn., University of Chicago Press, Chicago.

Breed, G. \& Breed, D.G., 2010, 'Besinning oor die diakonale dienswerk na aanleiding van Handelinge 6:1-7', In Die Skriflig 44(3/4), 627-653.

Breed, G., 2012a, 'Nuut gedink oor die wese en inhoud van die dienswerk van die diaken', HTS Teologiese Studies/Theological Studies 68(1), 1-8. http://dx.doi. org/10.4102/hts.v68i1.1059

Breed, G., 2012b, "n Begronde bedieningsmodel vir die diakonia van die gemeente', HTS Teologiese Studies/Theological Studies 68(2), 1-11. http://dx.doi.org/10.4102/ hts.v68i2.1107

Bruner, F.D., 2012, The Gospel of John: A commentary, Eerdmans, Grand Rapids.

Clarke, A.D., 2000, Serve the community of the church: Christians as leaders and ministers, Wm. B. Eerdmans Publishing, Grand Rapids.

Coetzee, J.C., 1976, 'n Pleidooi vir vernuwing in die besondere kanoniek - toegelig aan die hand van die evangelie van Johannes, Potchefstroomse Universiteit vir CHO, Potchefstroom. 
Collins, J.N., 1990, Diakonia: Re-interpreting the ancient sources, Oxford University Press, Oxford.

Collins, J.N., 1995, 'A Ministry for tomorrow's church', Journal of Ecumenical Studies 32(2), 159-178.

Collins, J.N., 2002, Deacons and the church: Making connections between old and new, MPG Books, Leomister.

Collins, J.N., 2006, 'Ordained and other ministries: Making a difference', Ecclesiology 3(1), 11-32. http://dx.doi.org/10.1177/1744136606067673

Collins, J.N., 2009, 'Re-interpreting diakonia in Germany', Ecclesiology 5, 69-81. http:// dx.doi.org/10.1163/174553108X378495

Dennis, J., 2006, 'Jesus' death in John's gospel: A survey of research from Bultmann to the present with special reference to the Johannine hyper-texts', Currents in Biblical Research 4(3), 331-363. http://dx.doi.org/10.1177/1476993X06064628

Donfried, K.P., 1990, 'Ministry: Rethinking the term diakonia', Concordia Theological Quarterly' 56 (1), 1-15.

Elliot, J.H., 2000, 1 Peter: A new translation with introduction and commentary, Doubleday, New York.

Gooder, P., 2006, 'Diakonia in the New Testament: A dialogue with John N. Collins', Ecclesiology 3(1), 33-56. http://dx.doi.org/10.1177/1744136606067678

Hamilton Jnr., J.M., 2010, God's glory in salvation through judgement: A Biblical theology, Crossway, Wheaton IL.

Hannaford, R., 2005, 'Representation and the theology of ministry', Ecclesiology 1(2), 75-94. http://dx.doi.org/10.1177/1744136605051888

Hartley, B.L., 2004, 'Connected and sent out: Implications of new Biblical research for the United Methodist diaconate', Quarterly Review 24(4), 367-380.

Hentschel, K., 2007, Diakonia im Neuen Testament: Studien zur Semantik unter besonderer Berücksichtigung der Rolle von Frauen, Mohr Siebeck, Tübingen.

Kim, B., 1999, 'The voice from heaven in the gospel of John: Meaning and function of John 12:20-36', Modiss, Kampen.

Koester, C.R., 2005, 'The death of Jesus and the human condition: Exploring the theology of John's Gospel', in J.R. Donahue (ed.), Life in abundance: Studies of John's Gospel in tribute to Raymond E. Brown, pp. 141-167, Liturgical Press, Minnesota.

Köstenberger, A.J. \& Swain, S.R., 2008, 'Father, Son and Spirit: The trinity and John's Gospel', in D.A. Carson (ed.), New studies in Biblical theology 24, pp. 7-224, Inter Varsity Press, Downers Grove.

Köstenberg, A.J., 2002, John, Zondervan, Grand Rappids.
Kysar, R., 2001, '“As You sent me": Identity and mission in the fourth gospel', Word \& World 21(4), 370-376.

Latvus, K., 2008, 'The paradigm challenged: A new analysis of the origin of diakonia', Studia Theologica 62, 142-157. http://dx.doi.org/10.1080/00393380802559816

Latvus, K., 2010, 'Diaconal ministry in the light of the reception and re-interpretation of Acts 6: Did John Calvin create the social-caritative ministry of diaconia?', Diaconia 1, 82-102.

Lee, D., 2010, 'The gospel of John and the five senses', Journal of Biblical Literature 129(1), 115-127.

Louw, J.P. \& Nida, J., 1988, Greek-English lexicon of the New Testament, based on semantic domains (2 vols.), UBS, New York.

MacArthur, J., 2005, Hard to believe: The high cost and infinite value of following Jesus, Thomas Nelson Inc, Nashville.

Moloney, F.J., 1998, 'The gospel of John', in D.J. Harrington (ed.), Sacra Pagina Series, vol. 4, n.p., The Liturgical Press, Minesota.

Moloney, F.J., 2005, The Gospel of John: Text and context, Brill, Boston.

Mullins, M., 2003, The gospel of John, The Columba Press, Dublin.

Neyrey, J.H., 2007, 'The gospel of John', in B. Witherington (ed.), The new Cambridge Bible Commentary, n.p., Cambridge University Press, New York.

Obielosi, D.C., 2008, Servant of God in John, Peter Lang, Frankfurt am Main. (European University Studies, Series XXIII, Theology).

Painter, J., 1991, The quest for the messiah: The history, literature and theology of the Johannine community, T\&T Clark, Edinburgh.

Ridderbos, H., 1992, Het evangelie naar Johannes, deel 2, Kok, Kampen.

Romanowsky, J.W., 2005, “'When the Son of man is lifted up": The redemptive power of the crucifixion in the Gospel of John', Horizons 32(1), 100-116. http://dx.doi. org/10.1017/S0360966900002218

Salier, W.H., 2004, The rhetorical impact of the semeia in the gospel of John, Mohr Siebeck, Sydney. (Wissenschafliche Untersuchugen zun neuen Testament).

Thomas, J.C., 2004, Footwashing in John 13 and the Johannine Community, T\&T Clark, London.

Van der Watt, J., 2008, 'Johannine style: Some initial remarks on the functional use of repetition in the gospel according to John', In die Skriflig 42(1), 91.

Von Wahlde, U.C., 2010, The gospel and letters of John, vol. 2, Commentary on the Gospel of John, Eerdmans, Michigan. (Eerdmans Critical Commentary). 